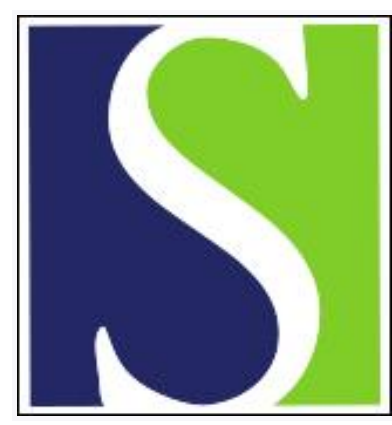

Scand J Work Environ Health 1994;20(3):216-222

https://doi.org/10.5271/sjweh.1405

Issue date: 01 Jun 1994

Acute respiratory disorder, rhinoconjunctivitis and fever associated with the pyrolysis of polyurethane derived from diphenylmethane diisocyanate.

by Littorin M, Truedsson L, Welinder H, Skarping G, Martensson U, Sjoholm AG

Affiliation: Department of Occupational and Environmental Medicine, University Hospital, Lund, Sweden.

This article in PubMed: www.ncbi.nlm.nih.gov/pubmed/7973495 


\title{
Acute respiratory disorder, rhinoconjunctivitis and fever associated with the pyrolysis of polyurethane derived from diphenylmethane diisocyanate
}

\author{
by Margareta Littorin, MD, ${ }^{1}$ Lennart Truedsson, MD, ${ }^{2}$ Hans Welinder, MSc, ${ }^{1}$ \\ Gunnar Skarping, PhD, ${ }^{1}$ Ulla Mårtensson, ${ }^{2}$ Anders G Sjöholm, MD ${ }^{2}$
}

\begin{abstract}
LITTORIN M, TRUEDSSON L, WELINDER H, SKARPING G, MÅRTENSSON U, SJÖHOLM AG. Acute respiratory disorder, rhinoconjunctivitis and fever associated with the pyrolysis of polyurethane derived from diphenylmethane diisocyanate. Scand J Work Environ Health 1994;20:216-22.

OBjectives - A case is described of complex reactions associated with exposure to diphenylmethane diisocyanate (MDI), with some immunologic observations.

Methons - Medical history, clinical examinations, and analyses of immunologic parameters and the 4,4'-MDI-related amine 4,4'-diaminodiphenylmethane (MDA) in hydrolyzed serum and urine were used. RESULTS - The patient, a mechanic whose medical history suggested repeated attacks of a work-related pulmonary or systemic disease, was examined because of acute respiratory disorder, rhinoconjunctivitis, and a late systemic reaction after exposure to polyurethane pyrolysis products, including 4,4'-MDI (air level $15 \mu \mathrm{g} \cdot \mathrm{m}^{-3}$ ). Spirometry showed a partly reversible obstructive dysfunction, and a skin-prick test was positive versus isocyanates conjugated with human serum albumin (HSA). MDA was detected in hydrolyzed serum $(5.6 \mathrm{ng} \cdot \mathrm{ml})$ and urine $\left(1.6 \mu \mathrm{g} \cdot \mathrm{g}\right.$ creatinine $\left.\mathrm{e}^{-1}\right)$. In serum, there were specific immmunoglobulin (Ig) $\mathrm{G}$ (IgG1 and IgG4) and IgE antibodies to 4,4'-MDI-HSA and other isocyanates (phenylisocyanate, toluene diisocyanate, $p$-toluene monoisocyanate, hexamethylene diisocyanate) conjugated with HSA, a very high total $\mathrm{IgE}$, a raised total $\mathrm{IgG}$, and moderate neutrophilia and eosinophilia. The specific antibodies declined, but were still increased five years later. Furthermore, the values of circulating immune complexes were high. In vitro, the circulating immune complexes in serum increased after the addition of 4,4'-MDI-HSA. The patient had anti-C1q antibodies, which probably accounted for part of the circulating immune complexes.

Conclusions - The reactions associated with MDI exposure (in combination with exposure to pyrolysis products) had features compatible with immediate hypersensitivity and with a complementmediated immune-complex reaction.
\end{abstract}

KeY TERMS - allergy, hypersensitivity, isocyanate, immune complexes, isocyanate-specific IgE and IgG, lung disorder, occupational, systemic reaction.

Because of its low vapor pressure diphenylmethane diisocyanate (MDI) was originally considered to have a low potential to induce disease. However, in connection with spraying, or heating, MDI has been associated with both asthmatic and systemic reactions $(1-4)$. The mechanisms behind these diseases are still controversial. Pharmacological, immunologic, and irritant mechanisms have been suggested. The present case report concerns clinical and immunologic aspects of the adverse reactions resulting from the heating of polyurethane (PU) resin, derived from MDI. The main component of technical grade MDI is normally the $4,4^{\prime}$-isomer.

1 Department of Occupational and Environmental Medicine, University Hospital, Lund, Sweden.

2 Department of Medical Microbiology, Lund University, Lund, Sweden.

Reprint requests to: Dr M Littorin, Department of Occupational and Environmental Medicine, University Hospital, S-22185 Lund, Sweden.

\section{Case}

History. The patient was a 45-year-old mechanic. In 1976, he started to manufacture, assemble, and repair conveyer belts [made of PU, polyvinyl chloride (PVC), polyester, or natural fibers] in his workshop and in different factories. He joined PU or PVC belts using high-frequency welding or a homemade tool, which heated the material electrically to 150 $170^{\circ} \mathrm{C}$. He also imprinted belts with another homemade tool, a metal roller, while blowing hot air $\left(350-600^{\circ} \mathrm{C}\right)$ on the surface of the belts.

The patient had never had any allergic manifestations. He was a smoker (about 30 cigarettes daily). In 1970 he had unilateral optic neuritis. In January 1984 he was hospitalized, after three weeks of coughing with hemoptysis, because of a pulmonary infiltrate in the right upper lobe. The infiltrate only gradually subsided after he was put on antibiotics. Bronchoscopy revealed generalized bronchitis. Two months later, he had a flu-like illness. In July 1986 he spent $24 \mathrm{~h}$ in the hospital under the diagnosis "virosis," because of repeated attacks of myalgia, 
fever, and shivering during the preceding fortnight. His temperature was $38.7^{\circ} \mathrm{C}$ at admission, (next morning $37.0^{\circ} \mathrm{C}$ ). He had been working with isocyanate glue for about a week, and, on the day of hospitalization, had been joining PU conveyer belts.

In the beginning of November 1986, he had been imprinting on a PU-impregnated conveyer belt $(19 \times$ $0.4 \mathrm{~m}$; PU surface $0.8 \mathrm{~mm}$ thick) for $5 \mathrm{~h}$ in a bakery. After work, he suffered from chest tightness. Between 1300 and 1500 in the afternoon on the 19th of November, he had again imprinted on the belt. He used no respiratory protective equipment. Fifteen minutes later he was struck with heavy respiratory distress, which lasted for about $30 \mathrm{~min}$. He left the workplace with a sore throat, stuffy nose, and red eyes. At 2000, he was beginning to chill and shiver. At midnight, his temperature was $38.8^{\circ} \mathrm{C}$ and at 0600 the next morning it was $37.6^{\circ} \mathrm{C}$. In the physical examination made at 0800 , there was nose congestion, bilateral conjunctivitis, edema of the eyelids, and sparse crepitating rales on the left lung base. During the ensuing $10 \mathrm{~d}$, the symptoms and signs gradually subsided.

Exposure. According to the PU conveyer-belt producer, the PU was supposedly derived from toluene diisocyanate (TDI). In January 1988, to confirm the alleged exposure, the patient (wearing a coal-filter respiratory mask) experimentally repeated, in his workshop, the imprinting job he had done in the bakery. The smoke contained $170(0.2 \mathrm{~m}$ above the belt $)$ and 15 (respiratory zone) $\mu \mathrm{g} 4,4^{\prime}-\mathrm{MDI} \cdot \mathrm{m}^{-3}$, but no TDI. (For the method see reference 5.) An 4,4'-MDIrelated amine, 4,4'-diaminodiphenylmethane (MDA), but not the TDI-related amine, toluenediamine, was detected in hydrolyzed serum $\left(5.6 \mathrm{ng} \cdot \mathrm{ml}^{-1}\right)$ and urine $\left(1.6 \mu \mathrm{g} \cdot \mathrm{g}\right.$ creatinine $\left.{ }^{-1}\right)$ on 20 November 1986 [as determined by gas chromatography and selected ion monitoring (unpublished observations and reference 6)]. Decreasing levels of MDA were found in serum and urine during the following months and days, respectively. (A bystander, without respiratory protection, exposed for $24 \mathrm{~min}$ during the aforementioned pyrolysis experiment in the workshop, had serum levels of 0.03 before the exposure and $2.7 \mathrm{ng}$ $\mathrm{MDA} \cdot \mathrm{ml}^{-1} 0.5 \mathrm{~h}$ after it.)

Clinical examinations. An $\mathrm{X}$ ray of the lungs (20 November 1986) displayed slight atelectases on the left base, present already in 1984. Spirometry showed a vital capacity of 5.11 (same as in 1984), expected $5.6 \mathrm{l}$, and a forced vital capacity in $1 \mathrm{~s}\left(\mathrm{FEV}_{\mathrm{I} .0}\right)$ of 3.51 (4.1 1 in 1984), expected 4.31. The volume of trapped gas was $2.7 \%$ of the total lung capacity (upper reference limit $2.0 \%$ ). The gas distribution and the carbon-monoxide diffusion-capacity were normal. In May 1987, as well as in January 1988, the
$\mathrm{FEV}_{1.0}$ was again higher, $4.0 \mathrm{l}$ (both times), and the vital capacity was 4.8 and 5.01 , respectively.

Skin-prick tests with isocyanate $\left[4,4^{\prime}\right.$-MDI, phenylisocyanate $(\mathrm{PhI})$, TDI, $p$-toluene monoisocyanate ( $p$-TMI), hexamethylene diisocyanate (HDI)] conjugates with human serum albumin (HSA) evoked positive responses to all of the substances (wheal at least half that induced by histamine). The skin-prick test with 13 common allergens was negative.

Routine laboratory tests. The erythrocyte sedimentation rate rose from $12 \mathrm{~mm}$ on November 20th to $22 \mathrm{~mm}$ on November 25th. Electrophoresis samples of serial blood revealed acute inflammatory activity and, especially, an increase in orosomucoid. On November 20th, the neutrophilic cell count was $7.9 \cdot 10^{9} \cdot \mathrm{l}^{-1}$ and had, on November $21 \mathrm{st}$, decreased to $3.3 \cdot 10^{9} \cdot 1^{-1}$. Eosinophils reached a maximum of $0.8 \cdot 10^{9} \cdot 1^{-1}$ on November 21 st and a base level of $0.2 \cdot 10^{9} \cdot 1^{-1}$ on December 8th. The total immunoglobulin (Ig) A and total IgM were maximal on November 25th, 2.55 and $1.5 \mathrm{~g} \cdot \mathrm{l}^{-1}$, respectively, and 2.04 and $1.2 \mathrm{~g} \cdot \mathrm{l}^{-1}$, respectively, on December $12 \mathrm{th}$. The total $\operatorname{IgG}$ (figure 1) and, especially, the total $\operatorname{IgE}$ (figure 2) were elevated. There were no specific IgE antibodies against common allergens and no rheumatoid (Waaler-Rose) or antinuclear (ANA) antibodies. Much later, in 1993, Sjögren's syndrome (SS-A) autoantibodies were found.

Genetic typing. The patient's human leucocytlocus A type was A2, 24; B7; Cw7; DR2, 6. The phenotype of the complement protein $\mathrm{C} 4$ was $\mathrm{C} 4 \mathrm{~A} 3, \mathrm{C} 4 \mathrm{~B} 1$. $\mathrm{He}$ was a rapid acetylator (in Dapsone ${ }^{\circledR}$ and $\mathrm{N}$ acetylation transpherase 2 genotype tests).

Immunologic analyses. Specific IgG [figure 1, ELISA (7)], and specific IgE [figure 2, RAST (7)] antibodies against 4,4'-MDI, PhI, TDI, $p$-TMI, and HDI conjugates with HSA were markedly increased. In addition, specific IgG (absorbance) and IgE (percentage of binding) antibodies against phthalic anhydride (PA) conjugate with HSA were elevated [IgG 1.3, upper reference limit 0.5; IgE 17, upper reference limit $0.3(8)$ ]. RAST (method from reference 9) and ELISA inhibition tests supported the specificity (IgE against isocyanates and PA, IgG against 4,4'-MDI-HSA). As to subclasses, IgG1 and IgG4, antibodies to isocyanate and PA were present at levels above normal; the absorbance values for IgG4 were at least 20 times for 4,4'-MDI, PhI, and $p$-TMI, and for IgGl more than 10 times, the upper reference limit. The specific IgM isotype antibodies were low. (For the method see reference 8.).

The RAST values for specific IgE against 4,4'MDI-HSA decreased after the end of the exposure (initial half-time one to two months), but they were 


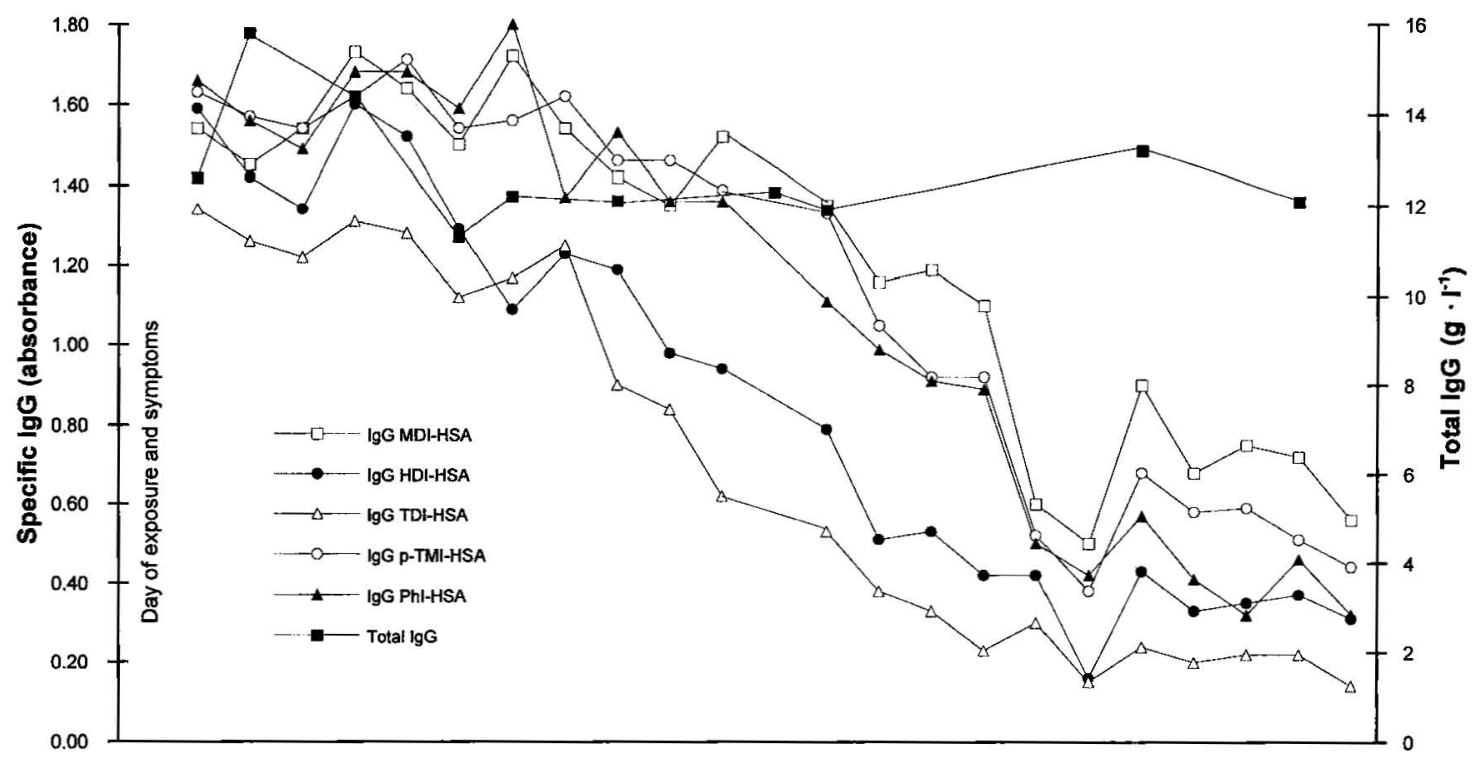

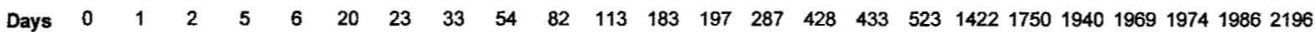

1986

1987

- 1988 - 19901991

1992

Figure 1. Serum levels of total immunoglobulin $\mathrm{G}(\mathrm{IgG})$, and specific $\lg \mathrm{G}$ antibodies to conjugates of isocyanates and human serum albumin (HSA) in a patient exposed to diphenylmethane diisocyanate (MDI) (day $0=19$ November 1986). [IgG MDI-HSA = specific IgG to 4,4'-MDI-HSA, IgG HDI-HSA = specific IgG to HDI (hexamethylene diisocyanate)-HSA, IgG TDI$\mathrm{HSA}=$ specific IgG to TDI (toluene diisocyanate)-HSA, IgG $p$-TMI-HSA = specific IgG to $p$-TMI ( $p$-toluene monoisocyanate)HSA, IgG PhI-HSA = specific IgG to $\mathrm{Phl}$ (phenylisocyanate)-HSA, upper reference limit for total $\operatorname{lgG}=\left.12.6 \mathrm{~g} \cdot\right|^{-1}$, for specific IgG (absorbance) versus MDI-HSA, TDI-HSA, and $p$-TMI-HSA = 0.2 and versus PhI-HSA and HDI-HSA =0.3; total IgG was measured only at dates as indicated — this is not a linear scale.]

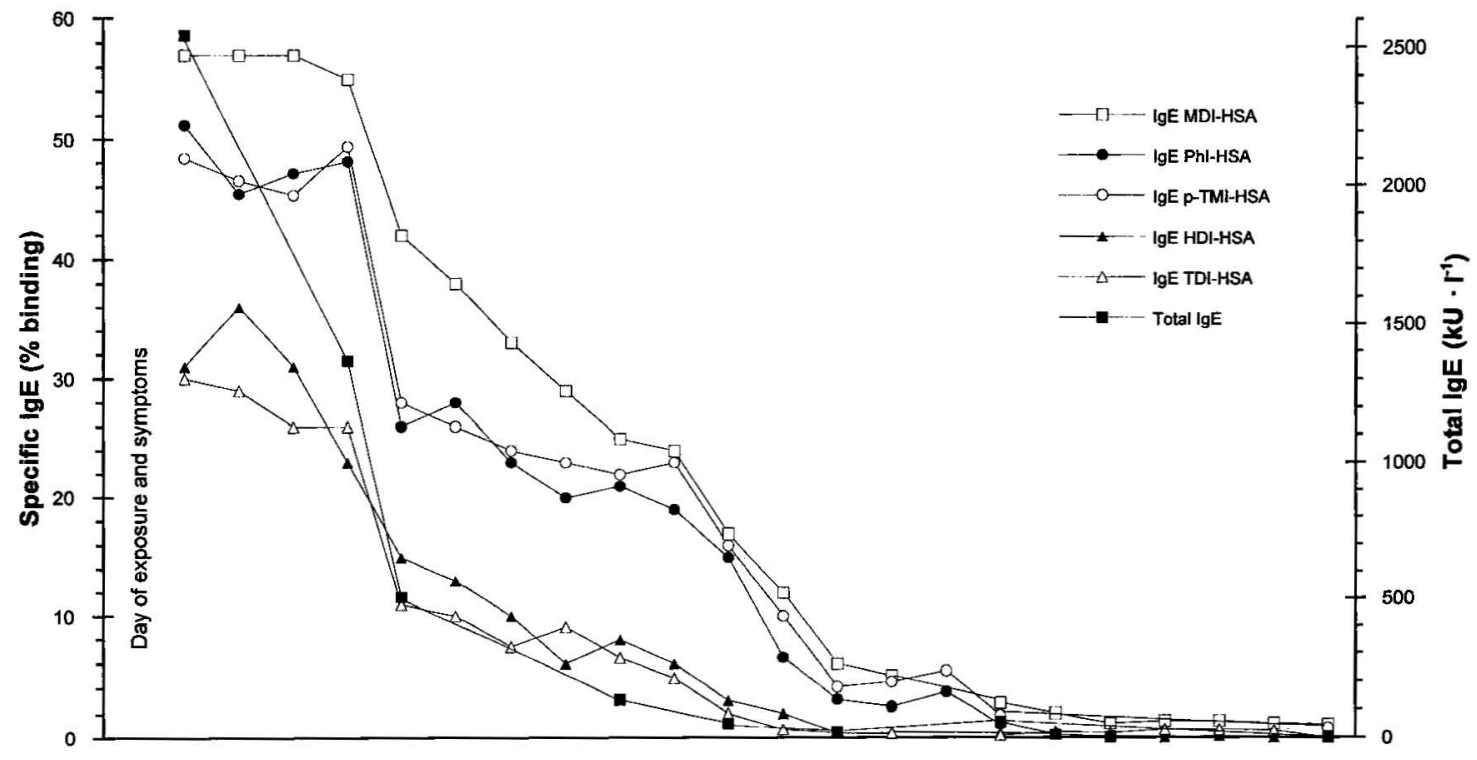

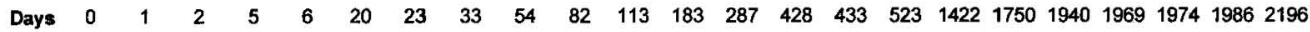

1986

1987

- 1988 - 19901991

1992

Figure 2. Serum levels of total immunoglobulin $E(\lg E)$ and specific $\lg E$ antibodies to conjugates of isocyanates and human serum albumin (HSA) in a patient exposed to diphenylmethane disocyanate (MDI) (day $0=19$ November 1986). [lgE MDI-HSA = specific lgE to 4,4'-MDI-HSA, IgE PhI-HSA = specific IgE to Phl (phenylisocyanate)-HSA, IgE $p$-TMI-HSA = specific IgE to $p$-TMI ( $p$-toluene monoisocyanate)-HSA, IgE HDI-HSA = specific IgE to HDI (hexamethylene diisocyanate)$\mathrm{HSA}$, IgE TDI-HSA = specific IgE to TDI (toluene diisocyanate)-HSA, upper reference limit for total IgE $=\left.100 \mathrm{kU} \cdot\right|^{-1}$, and for specific IgE isocyanate antibodies $=0.3 \%$ binding; total lgE (method: IMx assay, Abbott Laboratory By PRIST Pharmacia, total IgE was $3705 \mathrm{kU} \cdot \mathrm{l}^{-1}$ on day 1) was measured only at dates as indicated - this is not a linear scale.] 


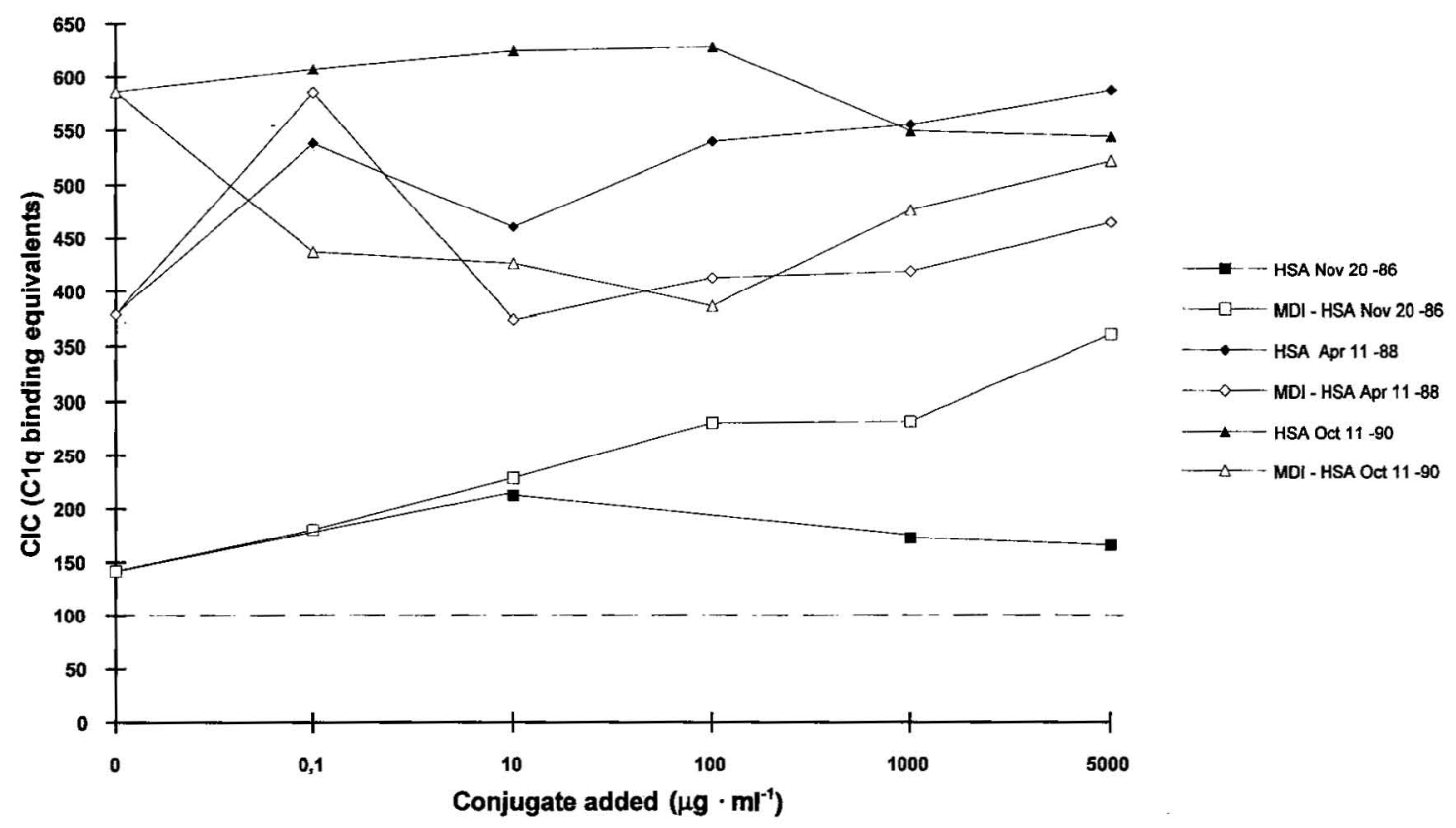

Figure 3. Circulating immune complexes $(\mathrm{CIC})$ in serum from a patient exposed to diphenylmethane diisocyanate (MDI) (19 November 1986), measured as C1q binding activity and expressed as equivalents of heat-aggregated IgG in micrograms per milliliter in sera after the addition of $1 / 10$ volume of aggregates in phosphate-buffered saline and incubation at $37^{\circ} \mathrm{C}$ for $1 \mathrm{~h}$, followed by the addition of ethylenediaminetetraacetic acid to $\left.5 \mathrm{mmol} \cdot\right|^{-1}$ (normal range $<100 \mathrm{C} 1 \mathrm{q}$ binding equivalents). (HSA = human serum albumin, MDI-HSA = conjugates of $4,4^{\prime}-\mathrm{MDI}$ and HSA; binding to MDI-HSA was compared with HSA - this is not a linear scale.]

still above the upper reference limit in September 1991 (day 1750 in figure 2). The ELISA values for IgG decreased even more slowly (figure 1). The IgG and $\operatorname{IgE}$ values versus TDI-HSA decreased somewhat faster.

No precipitating antibodies against 4,4'-MDI-HSA, TDI-HSA, or HDI-HSA were found in Ouchterlony analyses (3\% weight/volume PEG6000 added to the gel). The complement proteins $\mathrm{C} 1 \mathrm{q}, \mathrm{C} 1 \mathrm{~s}, \mathrm{C} 3$, and $\mathrm{C} 4$ in sera from 20 and 21 November 1986 were slightly increased. (For the method see reference 10). Circulating immune complexes were present above the normal range $(\mathrm{Clq}$ binding assay from reference 11 ; solid phase $\mathrm{C} 1 \mathrm{q}$ binding assay, modified from reference 12). In vitro, the addition of 4,4'-MDI-HSA (figure 3), or TDI-HSA (not shown), in increasing concentrations up to $5 \mathrm{~g} \cdot \mathrm{1}^{-1}$, gave a marked increase in the $\mathrm{Clq}$ binding activity in the serum. With samples obtained two and four years later, no such increase was seen, but the levels of circulating immune complexes in serum were high (figure 3 ).

The assessment of $\mathrm{C} 1$ activation [crossed immunoelectrophoresis (13)] showed an increased concentration of complexes containing $\mathrm{C} 1$ inhibitor, $\mathrm{C} 1 \mathrm{r}$, and $\mathrm{Cls}$ at the time of the exposure. In the sera obtained two and four years later, increased levels of complexes containing inhibitors of both $(\mathrm{Clr}-\mathrm{Cls}) 2$ and $\mathrm{C} 1$ were observed. Incubation of sera with $4,4^{\prime}-$ MDI-HSA did not result in $\mathrm{Cl}$ activation, neither were $\mathrm{C} 3 \mathrm{dg}$ fragments generated. (For the method see reference 14). Furthermore, there was no cleavage of C3 after incubation with TDI-HSA [crossed immunoelectrophoresis (15)]. Anti-Clq antibodies were found in serial serum samples collected since the exposure, the highest concentration occurring four years after the exposure, 280 arbitrary units $\cdot \mathrm{ml}^{-1}$ (upper reference limit 16; method from reference 16).

To elucidate any constitutional deviation, we determined peripheral blood lymphocyte markers for CD2, CD3, CD4, CD8, and CD19 using flow cytometric analysis and found them to be normal in 1990 , as was the stimulation of peripheral blood mononuclear cells (PBMC) with phythemagglutinin or pokeweed mitogen. To study possible immunologic memory, PBMC and B-cell depleted PBMC (Dynabeads Pan-B [CD19], Dynal AS, Oslo) were incubated with 4,4'-MDI-HSA or with epoxy Mw 340 (DGEBA), but we found no stimulation of cells, as measured by the uptake of $3 \mathrm{H}$-thymidin.

Course of events. After November 1986, the patient began to use respiratory protective devices whenever he thought he might be substantially exposed to isocyanates. In January 1988 (day 428 in figures 1 and 2), he was reexamined in the hospital because of skin rash and papular eruptions on his hands (present for one and a half months) and facial edema (present about $10 \mathrm{~d}$ ). In connection with the onset of symptoms, he had started to use a new glue 
("super-epoxy"). In the examination, he showed an intense patch-test reaction against epoxy Mw 340, but not versus MDA, MDI, or other materials that he had used.

In March 1992, he had repeatedly heated PU materials without respiratory protection (before day 1940, figures 1 and 2). In April (day 1969), he imprinted on a belt (of unknown composition) in a bakery and was struck with acute respiratory distress, sore throat, chills and fatigue, lasting for about $24 \mathrm{~h}$.

\section{Discussion}

Already before the first examination for symptoms (November 1986), the patient had probably had repeated isocyanate-associated systemic reactions. The high values of specific immunoglobulins already in the very first blood samples at least indicated earlier exposure(s).

A noteworthy aspect is the inadequate information supplied by the manufacturer with regard to the composition of the conveyer belt. Thus the relevant isocyanate became fully clear only after an analysis of air, serum, and urine samples. The 4,4'-MDI-related amine, MDA, was detected in hydrolyzed serum and urine. In workers exposed to MDA as such, much higher levels (in urine) have been reported (17).

Furthermore, judged from the rough exposure measurements made later in the workshop, the exposure to MDI might have been below the permissible limit (in Sweden $50 \mu \mathrm{g} \cdot \mathrm{m}^{-3}$, time-weighted average). However, even such exposure, at least to TDI, may cause disease $(2,4)$. In the present case, though, the exposure has been complex.

In spite of the known exposure to $4,4^{\prime}-\mathrm{MDI}$ only, the patient had specific IgG and IgE antibodies to a variety of isocyanates (the highest values, though, for 4,4'-MDI) and PA. This finding could be due to other exposures or to cross-reactivity, possibly because of new antigenic determinants being formed $(2,18-19)$.

The specific $\operatorname{IgE}$ and $\operatorname{IgG}$ antibodies gradually disappeared after the supposed end of peak exposure to $\mathrm{MDI}$, in accordance with earlier studies of $\mathrm{IgE}$ and $\mathrm{IgG}$ isocyanate antibodies $(19-20)$ and $\mathrm{IgE}$ antibodies to other small organic molecules (21). Apparently, the IgE level decreased faster than that of IgG. IgE versus TDI-HSA decayed more rapidly than IgE versus 4,4'-MDI-HSA, perhaps due to a lower affinity of the specific TDI antibodies. The decrease of the total IgE and IgG level was faster than that of the specific antibodies. Thus, in addition, there seems to have been a polyclonal activation of B cells.

We do not know with certainty that the demonstrated specific antibodies played a pathogenetic role for the respiratory and systemic reactions. IgE antibodies have earlier mainly been associated with isocyanate asthma $(2-4,22)$, recently also with isocyanate-induced hemorrhagic pneumonitis (23). Our patient had a complicated clinical picture; possibly his rhinoconjunctivitis and acute dyspnea were IgEassociated.

4,4'-MDI-HSA-specific IgG antibodies may be an index of exposure $(3,7,22)$, but they may also be associated with asthmatic reactions (3-4, 24-25) and with a type III IgG-dependent hypersensitivity to $\mathrm{MDI}(19,26)$, presented as a flu-like syndrome in the case of our subject. Humoral, as well as cellular, immunity may be involved in the pathogenesis of hypersensitivity due to isocyanates and other organic agents $(3,23,27-29)$. The role of the $\mathrm{IgG}$ subclasses remains uncertain $(7-8)$.

The patient had circulating immune complexes that bound $\mathrm{Clq}$, and some increase in the complexes was observed after isocyanate conjugates were added to acute serum in vitro. This phenomenon might reflect the presence of antibodies related to the development of symptoms. The patient's sera showed the presence of excess ( $\mathrm{C} 1 \mathrm{r}-\mathrm{C} 1 \mathrm{~s}) 2$ complexes, also an earlier finding for patients with chronic urticaria or angioedema (30). Furthermore, IgG binding to collagen-like fragments of $\mathrm{Clq}$ was demonstrated in the sera. IgG reaction with $\mathrm{Clq}$ has been reported for patients with systemic lupus erythematosus $(16,31)$ and patients with hypocomplementemic urticarial vasculitis syndrome $(16,32)$. Our patient had neither of these diseases. The pathogenetic significance of $\mathrm{Clq}$ antibodies is not known (32). Possibly, our findings reflect an autoimmune response to antigenic stimulation from isocyanates. Anti-C $\mathrm{lq}$ antibodies have been suggested to be responsible for the majority of the solid-phase Clq-binding IgG in the sera of most patients with systemic lupus erythematosus (31), and such antibodies in our patient probably account for part of the circulating immune complexes (32). Decreased clearance of circulating immune complexes in the patient could not be ascribed to a deficiency of $\mathrm{C} 4 \mathrm{~A}$, the $\mathrm{C} 4$ isotype most efficient in processing immune complexes (33).

This case shows that isocyanate-associated disease has to be considered in cases with unclear respiratory and general symptoms and signs. The presence of specific antibodies was the main finding, and the complement system was probably also involved. The finding of antibodies to Clq suggests an autoimmune reaction; this reactivity may have influenced the patient's symptoms. The presence (in 1993) of SS-A antibodies gives some further support to the possibility of an autoimmune disposition in this patient, as does his history of optic neuritis, a disease in which autoimmune mechanisms might be involved (34).

The mechanism behind isocyanate-related illness is still obscure. The present case might have a general bearing on mechanisms. It is possible that the features of our patient's disease that seem unique are not really so - but have simply not been studied earlier. Our findings should form a basis for epidemiologic approaches. More basic information concern- 
ing immunologic characteristics and predisposing host factors is certainly needed.

\section{Acknowledgments}

This work was supported by grants from the Swedish Work Environment Fund, the Swedish Medical Research Council (projects no 10381 and 7921), the Medical Faculty of the University of Lund, the Swedish National Association against Rheumatism, the King Gustaf V 80th Birthday Fund, the M Bergvall Trust, the Greta and Johan Kock Trusts, the Professor Nanna Svartz' Trust, the Thelma Zoéga Trust, and the A Østerlund Trust.

We thank Dr M Arborelius, Jr, MD, for his kind cooperation, and $\mathrm{Mr} \mathrm{M}$ Adamsson for his skillful assistance.

\section{Addition to proof}

In 1994, the patient developed crescentic glomerulonephritis with autoantibodies against myeloperoxidase. This development underscores his autoimmune disposition. The significance of his isocyanate reactivity (in 1994 he still has IgE and IgG isocyanate antibodies), if any, is unknown.

\section{References}

1. Zeiss CR, Kanellakes TM, Bellone JD, Levitz D, Pruzansky JJ, Patterson R. Immunoglobulin E-mediated asthma and hypersensitivity pneumonitis with precipitating anti-hapten antibodies due to diphenylmethane diisocyanate (MDI) exposure. J Allergy Clin Immunol 1980;65:346-52.

2. Hagmar L, Nielsen J, Skerfving S. Clinical features and epidemiology of occupational obstructive respiratory disease caused by small molecular weight organic chemicals. Monogr Allergy 1987;21:42-58.

3. Vandenplas O, Malo J-L, Saetta M, Mapp CE, Fabbri LM. Occupational asthma and extrinsic alveolitis due to isocyanates: current status and perspectives. $\mathrm{Br} J$ Ind Med 1993;50:213-28.

4. Banks DE, Balaan MR. The respiratory effects of isocyanates. In: Rom WN, ed. Environmental and occupational medicine. 2nd ed. Boston, MA: Little, Brown and Company, 1992:967-86.

5. Sangö C, Zimersson E. A new reagent for determination of isocyanates in working atmospheres by HPLC using UV or fluorescence detection. J Liq Chromatogr 1980;3:971-90.

6. Tiljander A, Skarping G, Dalene M. Chromatographic determination of amines in biological fluids with special reference to the biological monitoring of isocyanates and amines. J Chromatogr 1989;479:14552.

7. Welinder H, Nielsen J, Bensryd I, Skerfving S. IgG antibodies against polyisocyanates in car painters. Clin Allergy 1988; 18:85-93.

8. Nielsen J, Welinder H, Schntz A, Skerfving S. Specific serum antibodies against phthalic anhydride in occupationally exposed subjects. J Allergy Clin Immunol 1988;82:126-33.

9. Welinder H, Nielsen J, Gustavsson C, Bensryd I, Skerfving $S$. Specific antibodies to methyltetrahydrophthalic anhydride in exposed workers. Clin Exp Allergy 1990;20:639-45.

10. Johnson U, Truedsson L, Gustavii B. Complement components in 100 newborn infants and their mothers determined by electroimmunoassay. Acta Path Microbiol Immunol Scand Sect C 1983;91:147-50.

11. Zubler RH, Lange G, Lambert PH, Miescher PA. Detection of immune complexes in unheated sera by a modified 125I-Clq binding test: effect of heating on the binding of $\mathrm{Clq}$ by immune complexes and application of the test to systemic lupus erythematosus. J Immunol 1976;116:232-5.

12. Scullion M, Balint G, Whaley $\mathrm{K}$. Evaluation of the $\mathrm{Clq}$ solid phase binding assay for immune complexes: a clinical and laboratory study. J Clin Lab Immunol $1976 ; 2: 15-22$.

13. Laurell A-B, Mortensson U, Sjöholm AG. Cl subcomponent complexes in normal and pathological sera studied by crossed immunoelectrophoresis. Acta Pathol Microbiol Scand. Sect C 1976; 84:455-64.

14. Brandslund I, Siersted HC, Svehag S-E, Teisner B. Double-decker rocket immunoelectrophoresis for direct quantitation of complement $\mathrm{C} 3$ split products with C3d specificities in plasma. J Immunol Methods 1981; 44:63-71.

15. Sjöholm AG. Complement components and complement activation in acute poststreptococcal glomerulonephritis. Int Arch Allergy Appl Immunol 1979;58: 274-84.

16. Mortensson U, Sjöholm AG, Sturfelt G, Truedsson L, Laurell A-B. Western blot analysis of human IgG reactive with the collagenous portion of $\mathrm{Clq}$ : evidence of distinct binding specificities. Scand $\mathbf{J}$ Immunol 1992; 35:735-44.

17. Cocker J, Gristwood W, Wilson HK. Assessment of occupational exposure to 4,4'-diaminodiphenylmethane (methylene dianiline) by gas chromatographymass-spectrometry analysis of urine. $\mathrm{Br} \mathrm{J}$ Ind Med $1986 ; 43: 620-5$

18. Wass U, Belin L. Immunologic specificity of isocyanate-induced $\mathrm{IgE}$ antibodies in serum from 10 sensitized workers. J Allergy Clin Immunol 1989;83:12635 .

19. Malo JL, Ouimet G, Cartier A, Lewitz D, Zeiss CR. Combined alveolitis and asthma due to hexamethylene diisocyanate (HDI), with demonstration of crossed respiratory and immunologic reactivities to diphenylmethane diisocyanate (MDI). J Allergy Clin Immunol 1983;72:413-9.

20. Butcher BT, O'Neill CE, Reed MA, Salvaggio JE, Weill H. Development and loss of toluene diisocyanate reactivity: immunologic, pharmacologic, and provocative challenge studies. J Allergy Clin Immunol 1982; 70:231-5.

21. Venables KM, Topping MD, Nunn AJ, Howe W, Newman Taylor AJ. Immunologic and functional consequences of chemical (tetrachlorophthalic anhydride)induced asthma after four years of avoidance of exposure. J Allergy Clin Immunol 1987;80:212-8.

22. Liss GM, Bernstein DI, Moller DR, Gallagher JS, Stephenson RL, Bernstein IL. Pulmonary and immunologic evaluation of foundry workers exposed to methylene diphenyldiisocyanate (MDI). J Allergy Clin Immunol 1988;82:55-61.

23. Patterson R, Nugent KM, Harris KE, Eberle ME. Immunologic hemorrhagic pneumonia caused by isocyanates. Am Rev Respir Dis 1990;141:226-30.

24. Cartier A, Grammer L, Malo J-L, Lagier F, Ghezzo $\mathrm{H}$, Harris $\mathrm{K}$, et al. Specific serum antibodies against isocyanates: association with occupational asthma. $\mathrm{J}$ Allergy Clin Immunol 1989;84:507-14.

25. Grammer LC, Harris KE, Malo J-L, Cartier A, Patterson $\mathrm{R}$. The use of an immunoassay index for antibodies against isocyanate human protein conjugates and application to human isocyanate disease. $\mathbf{J}$ Allergy Clin Immunol 1990;86:94-8.

26. Bascom R, Kennedy TP, Levitz L, Zeiss CR. Specif- 
ic bronchoalveolar lavage IgG antibody in hypersensitivity pneumonitis from diphenylmethane diisocyanate. Am Rev Respir Dis 1985;131:463-5.

27. Schatz M, Patterson R, Fink J. Immunopathogenesis of hypersensitivity pneumonitis. J Allergy Clin Immunol 1977;60:27-37.

28. Yoshizawa Y, Ohtsuka M, Noguchi K, Uchida Y, Suko $M$, Hasegawa S. Hypersensitivity pneumonitis induced by toluene diisocyanate: sequelae of continuous exposure. Ann Intern Med 1989;110:31-4.

29. Salvaggio JE. Recent advances in pathogenesis of allergic alveolitis. Clin Exp Allergy 1990;20:137-44.

30. Laurell A-B, Mortensson U, Sjöholm AG. Studies of $\mathrm{Cl}$ subcomponents in chronic urticaria and angioedema. Int Arch Allergy Appl Immunol 1977;54:43442.

31. Wener MH, Uwatoko S, Mannik M. Antibodies to the collagen-like region of $\mathrm{Clq}$ in sera of patients with autoimmune rheumatic diseases. Arthritis Rheum 1989;32:544-51.

32. Wisnieski JJ, Naff GB. Serum IgG antibodies to Clq in hypocomplementemic urticarial vasculitis syndrome. Arthritis Rheum 1989;32:1119-27.

33. Gatenby PA, Barbosa JE, Lachmann PJ. Differences between $\mathrm{C} 4 \mathrm{~A}$ and $\mathrm{C} 4 \mathrm{~B}$ in the handling of immune complexes: the enhancement of CR1 binding is more important than the inhibition of immunoprecipitation. Clin Exp Immunol 1990;79:158-63.

34. Sergott RC, Brown MJ. Current concepts of the pathogenesis of optic neuritis associated with multiple sclerosis. Surv Ophthalmol 1988;33:108-16.

Received for publication: 22 June 1993 